\title{
LINDA HUTCHEON \\ Once Again, from the Top: \\ More Pomo Promo
}

Brian McHale, Constructing Postmodernism. London and New York: Routledge, 1992. xii +342 pp. $\$ 49.95 ; \$ 15.95$ paper.

Barry Smart, Postmodernity. London and New York: Routledge, 1993. 169 pp. $\$ 12.95$ paper.

Nicholas Zurbrugg, The Parameters of Postmodernism. Carbondale and Edwardsville: Southern Illinois University Press, 1993. xvi + 183 pp. \$19.95; $\$ 12.95$ paper.

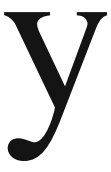

es, Virginia, there is a postmodernism. There must be. There are so many books about it, it has to exist. The question may be How many more re-viewings of the same theories and ideas can the topic bear, without the kind of major changes in evaluation or conceptualization that have kept the debates about modernism alive still today?

For literary postmodern junkies, Barry Smart's brief Postmodernity will be a useful fix on sociology's "take" on the titular concept, though those interested in cultural studies will also find this a helpful text. Part of Routledge's Key Ideas series, it is exemplary in its coverage of main issues, debates, and controversies around a term that has aroused everything from boosterism to scorn, advocacy to anger. Judicious and evenhanded in his discussions of the theorists and their ideas, Smart refuses to reduce the postmodern to a "preexisting and/or evolving modernity" and chooses instead to discuss particularly those contributions that he feels "consider the introduction of a concept of postmodernity appropriate and 
necessary for understanding current conditions" (13). His sociological definition of postmodernity, then, is as a broad contemporary social, political, and cultural condition, "a form of life, a form of reflection upon and a response to the accumulating signs of the limits and limitations of modernity" and to the "uncertainties and anxieties" they foster (12). Adept at teasing out the complexities of this condition and of the writings on it, Smart manages to place both in their historical contexts, and then to bring them to bear on the issue of the need to justify the practice of sociology, the need "to recall the specific historical, cultural and geopolitical conditions of its emergence and development, that is post-Enlightenment in Western Europe, and to contemplate its deconstruction and reconstitution" (69). Literary studies could do with even more of the same self-conscious reflection about its (very different) ethical basis and its special responsibilities.

Though more of a measured, analytic survey than an original essay in itself (for that, see Smart's Modern Conditions, Postmodern Controversies), 1 this book deals with the work of the major provocative theorists who either are or have influenced sociologists in their deliberations on postmodernity: Baudrillard, Touraine, Giddens, Bauman, Haberrnas, Rorty, Vattimo. But the chapter "Heretical Discourse" deals directly with literary texts, such as The Satanic Verses, which illustrate Smart's thesis that "in an age both blessed and burdened with a proliferating range of global communications technologies, the facility with which cultural boundaries may be crossed increases, as do the potential risks of offence, disagreement and conflict frequently associated with heresy and transgression" (113). And the section "Modern Reason, Postmodern Imagination" is an important contribution to the debates about the political agenda (or lack thereof) of the postmodern. Combining the positions of a number of major theorists, Smart suggests that what will be needed to deal with the social diversity and difference which define the postmodern condition is a combination of tolerance, solidarity, and imagination (106). He points to the pervasive questioning of social institutions and practices that is part of this condition, as is the

1. Barry Smart, Modern Conditions. Postmodern Controversies (New York: Routledge. 1992). 
"thorough-going reflexivity which leaves us with more questions than answers, and in consequence a conviction that modern knowledge does not so much precipitate an accumulation of certitudes as a proliferation of doubts" (105).

While more literary in focus, the other two books under review here would - in theory - second that reflexive description of the postmodern, though - in practice - both offer answers more than questions and suggest more master narratives of certitude than proliferations of doubts. While Brian McHale's Constructing Postmodernismessen tially revisits familiar territory-mapped by other critics as well as by McHale himself - Nicholas Zurbrugg's The Parameters of Postmodernism attempts a radical and provocative reconfiguration of the terrain. The new map repositions the center of cultural interest and productivity, moving it from the Old World to the New (or at least one part of it, the United States). Noting that European and American responses to the postmodern condition have been different, Zurbrugg then separates what he calls the "B-effect"-the negative definitions and reactions of European critics like Benjamin, Barthes, Burger, Baudrillard, Bonito-Oliva, Bourdieu, Belsey, and any others unlucky to be born with a B-name - from the more positive "C-effect"- the experimental, avant-garde creative work of American artists like John Cage. Is this like comparing apples and oranges? Is it a reductive noncomparison? It is both, in a sense, but that doesn't stop the polemic from being engagingly provocative at times. On the (bad) B-effect side, there is stagnant, musty old Europe, full of apocalyptic, wailing critics; on the (creative) C-effect side, there is the United States, full of "vital," "intelligent," flexible" (adjectives that are repeated often) multimedia artists who delight in the utopian, extrarational, technological possibilities of the postmodern. The fact that one of the most negative of critics of the postmodern is American (Fredric Jameson) is dealt with in its own section; the fact that there are European artists-Peter Maxwell Davies, Angela Carter, Karlheinz Stockhausen, Anselm Kiefer, and the list could go on-who might well count as C-effect sorts is not even considered, in the author's enthusiasm for things American. (There is also curiously but characteristically little said about the rest of the world, even the Western world, which Amerocentric visions like this often ignore.) 
The trouble is that the book (unselfconsciously?) illustrates its thesis in its own schizophrenic rhetoric: more negative about the Beffect critics than the most negative of them ever are about the postmodern, it is frequently both reductive and dismissive in its dealings with their often complex theories. Some critics are simply said to be "misleading" (84), others "misguided" (161), but no evidence (other than disagreeing with the book's thesis) is given for these judgments. This B-effecting of the B-effect is matched by the unbridled C-effect enthusiasm the book shows for the C-effect artists, from Kathy Acker to Ellen Zweig, whom Zurbrugg has interviewed and cites here at length. He calls this "empirical analysis," but it may well be the revenge of the "intentional fallacy," instead. There is no analysis of authorial statements-or work, for that matter; assertions substitute for argument. This is clearly polemic. This approach would not be so disturbing if we did not have other examples of fine analytic work, combined with equal enthusiasm, of some of the same material (though not cited or mentioned here) in Robert Siegle's excellent study, Suburban Ambush: Downtown Writing and the Fiction of Insurgency.2 With lucidity and wit, Siegle has managed to argue convincingly what Zurbrugg only states, going beyond polemic to analyze, contextualize, and historicize important American experimental artists. In the end, Zurbrugg's map may redraw the terrain, but it does so too sketchily to be of much use beyond being suggestive. Too many names are simply mentioned (dropped?), and the initially refreshing irreverence toward the Beffect critics becomes, by the end, condescending.

Despite major differences, Zurbrugg's book shares with Brian McHale's Constructing Postmodernism a number of formal and thematic features. Both critics have chosen to write in what McHale calls "blocks"- the artifacts of electronic word processing-but in both cases the resulting "discontinuous and suspensive organization" of which McHale writes with happy postmodern acceptance (15)is probably much more fun (and easier, frankly) for the writer than the reader. Zurbrugg's bits range from a half page to four pages and end up feeling like written equivalents of sound bites or

2. Robert Siegle, Suburban Ambush: Downtown Writing and the Fiction of Insurgency (Baltimore: Johns Hopkins UP, 1990). 
magazine-article units, with snappy, often punning subtitles and with the first phrase (needlessly) italicized. But upon closer examination, these little bits all follow one another like any other normally printed text would; in fact, some of the breaks feel irritatingly unmotivated and disrupt what is really sequential logic, though admittedly a logic that lacks conclusions. I can only assume that was the (postmodern) point, but it feels contrived - an attempt to look more trendy and experimental than it in fact really is. 3

McHale's short sections are and feel like more traditional units, though the titles are equally punning and postmodernly playful. The difficulty here is a different one. The chapters of Constructing Postmodernism are almost all essays that have appeared elsewhere, from 1979 to 1992. All are said to have been rewritten at least somewhat for this volume, and attempts are made at linking them (largely in notes referring to earlier chapters). But too much of the original occasion of publication often remains, and too frequently the same catch phrases, often describing a critic's position or a particular theory, are repeated from essay to essay, for this to feel either like a coherent book or like a new book with a new argument. With limited success, McHale tries to forestall these objections in his introductory remarks by making the occasional nature of the essays into a virtue, "appropriate to the book's theme of provisionality" (14). But the thirteen-year compositional time range leads to odd juxtapositions of style from chapter to chapter: McHale's style has happily become more chatty and accessible over time, and less "theorybound" as the theory became more assimilated.

Those dates (1979-1992), however, also frame McHale's 1987 book Postmodernist Fiction-for which this new collection is openly presented as both a defense and a corrective. 4 Throughout, McHale challenges anyone who reviewed or discussed that book, sometimes with undisguised hostility, sometimes with rueful acknowledgment that they might have a point. The following is typical of the tone of the responses:

3. Nor is there a consistent note format-some are in the text, others (for no apparent reason) in endnotes.

4. Brian McHale, Postmodernist Fiction (New York: Routledge, 1987). 
This last incidental misreading apart, I find I can agree with everything McHoul and Wills say; in fact, I believe I havealready said it myself, if not outright then in effect and by implication, in the present essay. Nevertheless, when they describe me as having a "hang-up with readers having to reconstruct what 'really' happened from what a character dreamed, hallucinated, etc." . . . Ido not recognize in this a description of my practice. Why not? Obviously, there has been some talking at cross-purposes somewhere, but where?

There follow two pages of critique of their misreading, at crosspurposes to his argumentation. I may be in a minority on this issue, bu I Ialways find this kind of defensive self-protection the least interesting part of any work that indulges in it: such responses never constitute real intellectual debate, but only a simulacrum of it. The inevitable delays in publication make serious and engaged response to books as well as to reviews impossible; so what we get instead is a kind of defensive apologia that may, in the end, be of more interest to the author than to the reader, especially when the testy personal tone enters in. In Constructing Postmodernism as a whole, almost as much energy is spent responding to other critics and surveying critical responses (to the fiction studied as well as to his own work) as is spent on the literature analyzed. I appreciate McHale's evident strong interest in the institutions of interpretation, but, though perhaps no one knows the vast writing on the postmodern (or on a writer like Pynchon) better than McHale, it seems a waste of his equally evident analytic talent to use it to give us yet another survey of this well-trodden turf.

Like Zurbrugg, McHale is never shy to call another critic "mistaken"-despite his lengthy assertion, upon which the entire book is alleged to be based, that there is no single correct interpretation of postmodernism but simply a series of strategic constructions. Almost the only constructs other than his own, however, that are treated with any sympathy are those of Dick Higgins and Fredric Jameson. Where the positions of other artists or critics get summarily dealt with, these do not. Jameson even warrants the only cautious (and nondismissive) disagreement in the book: "If this is what he means to imply (but perhaps I have misunderstood him 
here), then he is mistaken" (13). Like every other book on this topic, both Constructing Postmodernism and The Parameters of Postmodernism have to deal with Jam eson's earl y theorizing of the "cultural logic of late capitalism."> But where the latter is irreverent and critical ("Jameson appears to be the victim of his own rhetoric, addicted as it were, to . . . 'Word Authority' " [4]), the former (even in disagreement) is almost reverent, as might have been expected, given McHale's earlier Diacritics article in praise of Jameson's "masterful" master narrative of the postmodern."

Both books are carefully reflexive about their own form and about their theoretical positioning, particularly in the modernism/ postmodernism debates. Both, de spite strong stands on the differences, end up (as may, indeed, be utterly appropriate) conflating the two designations, though in different ways. Despite a final, neat chart of "The General Phases of Modernism and Postmodernism" (163), Zurbrugg's position is that, from the 1930s to the 1990s, postmodernism has simply repeated the stages that modernism went through from the 1880 s to the 1930s:

an initial era of apocalyptic panic accompanied by, or succeeded by, a mood of cynical or ludic creativity. Second, a phase of substantial experimentation. Third, a phase of apocalyptic panic accompanied by, or followed by, prophetic confidence in new modes of hybrid creativity.

The confusing conflation of "eras" within that definition, as well as the collapsing of major distinctions between the tw o "cultural dominants," may be necessary to Zurbrugg's categorization of C-effect artists, but its usefulness beyond those confines is questionable, given the totally modernist discourse in which postmodernism is consistently discussed: Zurbrugg's search for novelty, for the "unique original artist" (67) is one that even Jameson called a modernist urge. Each of these studies, despite its sometimes radical

5. The essay "Postmodernism, Or The Cultural Logic of Late Capitalism" was first published in 1984 in the New Left Review(146:53-92) and then became the introduction of the book Postmodern ism, or, The Cultural Logic of Late Capitalism (Durham, NC: Duke UP, 1991).

6. Brian McHale, "Postmode rnism, or the Anxiety of Master Narratives," Diacritics 22.1 (1992): 17- 33. 
rhetoric, is curiously "aestheticizing," or more accurately, perhaps, "depoliticizing" in its silence about issues of difference and "otherness" that Smart's work, along with that of many others in recent years, puts at the center of the postmodern debates.

McHale's thesis in his earlier book had been that "postmodernist fiction differs from modernist fiction just as a poetics dominated by ontological issues differs from one dominated by epistemological issues."? Despite the philosophical terminology, McHale's interest was largely formal or aesthetic. He later noted that it also implied a narrative of progress, as a writer's oeuvre moved from modern to postmodern:

What is missing from Postmodernist Fiction (though its traces may be detected there) is the counter-story according to which modernism and postmodernism are not successive stages in some inevitable evolution from less advanced to more advanced aesthetic forms, but rather alternative contemporary practices, equally "advanced" or "progressive," equally available, between which writers are free to choose.

(Constructing 207)

In his new book, McHale attempts to complicate that "misleading" implication and give the other story, through detailed analyses of Joyce's Ulysses (chapter 2), Pynchons Gravity's Rainbow (chapters 3 and 4) and Vineland (chapter 5), Eco's The Name of the Rose (chapter 6) and Foucault's Pendulum (chapter 7), McElroy's Women and Men (chapter 8), and Christine Brooke-Rose's work (chapter 9). As always, when McHale reads texts, these analyses are meticulous in their scholarship and insightful in their theoretically informed textual interpretations. The sections on the role of television in Vineland (125-41) and on postmodern angelology (200-206), as well as the final chapter "Towards a Poetics of Cyberpunk," are high points for me of the kind of carefully theorized and historicized readings McHale does so very well. In the end, though, the choice of texts to discuss felt as unmotivated as even McHale admits they were: given the fact that the original pieces that make up this book were all commissioned, he has ended up writing on a series of texts which, he then tries to convince us, just happen to be "the most typicallypost- 
modernist" (15) ones around. As with Zurbrugg's C-effect selection, the "postmodernism" of which these might be "typical" feels somehow arbitrarily defined.

That, however, is part of the point of McHale's book; it is, after all, called Constructing Postmodernism. Writing late in the history of this much-discussed cultural enterprise, McHale argues that

we must choose among competing constructions of postmodernism on the basis of various kinds of rightness or fit such as, for instance, validity of inference; internal consistency or coherence; representativeness of sample; appropriateness of scope; richness of interconnections; fineness of detail; and productivity, a story's capacity to generate other stories, to stimulate lively conversation, to keep the discursive ball rolling.

This book, like The Parameters of Postmodernism and Postmodernity, will at least keep the discursive ball rolling. Whether these books have added anything new to the discourse on the postmodern, something that might change its evaluation or conceptualization, is another question, the still unanswered one with which I began.It is unanswered (or perhaps even answered negatively) for me, in part, because of the surprising silence, in the two literary treatments, around the more politicized intersections of the postmodern with, most obviously, the postcolonial and the feminist.

What all three books certainly do illustrate is that, when it comes to writing about postmodernism, whatever the claims for incredulity toward metanarrative, metanarratives still thrive. They may be "turn [ed] down," as McHale puts it (24); the stakes may be lowered. But, yes, Virginia, there is a postmodern master narrative -indeed, several of them - no matter how much men [sic] might deny it. 